INFORMASI - ISSN (p) 0126-0650; ISSN (e) 2502-3837

Vol. 49. No. 1 (2019).pp 36-49.doi: http://doi.org/10.21831/informasi.v49i1.25396

\title{
SEMIOTICS OF BORDER (ANALYSIS OF BATAS, A FILM OF RUDI SOEDJARWO)
}

\author{
Indra Ramanda \\ indraramandao1@gmail.com \\ Sumekar Tanjung \\ sumekar.tanjung@uii.ac.id. \\ Communication Studies Program \\ Universitas Islam Indonesia
}

\begin{abstract}
This research was conducted to explain the presentation of the boundary meanings presented by Batas film through their character. The border becomes the front face of a country. The social conditions of people who are still lagging behind and far from infrastructure development make the people living in the border vulnerable to various problems. As a message delivery medium, meanings are represented by character in film. The author analyzed five scenes on each character in Batas film. These are, Ubuh's character is threatened by the bad people who chase her in the middle of the forest, Arif's character as a police officer who looking for the information in the community, Jaleswari's character who cares about education problems at the border, Adeus's character who has great desire for the advancement of the people at the border but get threats from individuals who do not want the people on the border to get a high education, the character of the Panglima who has power in the Dayak tribe community. This study uses a critical paradigm with a qualitative approach. The process describes the meaning of signs into denotations, connotations, and myths. The results of this study indicate that meanings are defined as areas that have complex problems. Access to transnational crime is still very easy as security is needed in the area. Despite the increase in technology and technology, the region must have the slightest education, strive to advance the regions, without prioritizing their own interests without ignoring the cultural values of their ancestors.
\end{abstract}

Penelitian ini dilakukan untuk menjelaskan reperesentasi makna batas yang dihadirkan oleh pembuat film Batas melalui karakter tokohnya. Perbatasan menjadi wajah terdepan dari suatu negara. Keadaaan sosial masyarakat yang masih tertinggal dan jauh dari pembangunan infrastruktur, membuat masyarakat suku Dayak yang tinggal di pedalaman rentan terhadap berbagai permasalahan. Sebagai medium penyampai pesan, film ini penting dikaji untuk menjelaskan bagaimana makna batas direpresentasikan 
melalui masing-masing karakter. Peneliti melakukan analisis terhadap lima scene pada masing-masing karakter dalam film Batas. Kelima scene tersebut adalah, karakter Ubuh yang terancam dengan adanya orang-orang jahat yang mengejar di tengah hutan, karakter Arif sebagai aparat penegak hukum yang mencari informasi di tengah masyarakat, karakter Jaleswari yang peduli terhadap masalah pendidikan yang terjadi di perbatasan, karakter Adeus yang memiliki keinginan besar demi kemajuan masyarakat di perbatasan namun mendapatkan ancaman dari oknum yang tidak ingin masyarakat di perbatasan mendapatkan pendidikan yang tinggi, karakter Panglima yang memiliki kuasa di masyarakat suku Dayak. Penelitian ini menggunakan paradigma kritis dengan pendekatan kualitatif. Proses analisis yang dilakukan adalah semiotika model Roland Barthes yang menjabarkan makna tanda menjadi denotasi, konotasi, dan mitos. Hasil penelitian ini menunjukkan bahwa makna batas dimaknai adalah daerah-daerah yang memiliki masalah kompleks. Akses kejahatan transnasional masih sangat mudah, sangat diperlukan pengamanan di daerah tersebut. Meskipun terjadi peningkatan teknologi dan teknologi, wilayah harus tetap memiliki pendidikan sekecil apapun, berjuang memajukan daerah, tanpa mementingkan kepentingan sendiri tanpa mengabaikan nilai budaya leluhurnya.

Keywords: Semiotics, Movie, Boundary, Character, Cinema

\section{INTRODUCTION}

The borders area become the frontline for a country. This becomes important in terms of security at the border. In addition to East Nusa Tenggara and Papua, the National Border Crossing Post (PLBN) of Indonesia which is the foremost fortress with other countries is also located in Entikong. Indonesia has around 17,508 islands where 67 of them are directly adjacent to other countries (Widiyanta, 2010). Tangkilisan (in Marwasta, 2016) explained that border lines are vertical fields that pass through the land surface, underground layers, and air the activities that take place in it. The areas on the right and left of the border line are called border areas. The border in Indonesia has a problem that is alarming. The infrastructure and facilities are the main obstacles in the development of rural areas on the border. The borders of Indonesia and Malaysia are proof of the incomplete development infrastructure in the remote areas. People of Entikong, for example, must travel approximately eight hours to the town of West Kalimantan to buy their needs or to sell the crop. It is inversely proportional when they want to go to Malaysia for shopping needs and trade. It only requires less than one hour to travel from Entikong National Park to
Malaysia which has complete infrastructure and facilities compared to the region.

The condition of the people at the border creates a lot of perception. Some have linked the problems with people's lives, infrastructure, state security, to illegal buying and selling such as human trafficking.

Meanwhile, most media highlighted this condition as gray, meaning that the media raised issues from existing realities and collaborated by processing the meanings that they construct themselves, and not in accordance with the existing reality.

Batas, the film of Rudi Soedjarwo, released in 2011, contained the content of social messages that questioned education on the Indonesia-Malaysia border, especially the Dayak culture. The movie tells about Jaleswari who was sent by the company to investigate educational programs on the border which are generally inhabited by Dayak Gun tribes. Tembawang Gun Village is one of the locations directly adjacent to Sarawak, Malaysia. The Gun Dayak tribe is known as the guards tribe, because they live between two countries, Indonesia and Malaysia. The life of this tribe is far from adequate access to infrastructure. The main access of the Dayak Gun people is through the Sekayam river by using a wooden boat. 
Livestock such as pigs are considered animals that bring good luck and they must maintain them properly for the sake of their survival. Pigs are considered to be very valuable animals because they can produce many offspring, so they provide benefits or blessings to the owner. With the existence of such trust, the customary law on pig animals is applied in this area. Villagers celebrate through rituals in gratitude for the abundance of blessings with traditional dances, slaughtering pigs, drinking wine, and performing worship dances.

Batas was directed by Rudi Soedjarwo with Marcella Zalianty as producers. Rudi Soedjarwo is one of the leading directors in Indonesia. His works are Bintang Jatuh (2000), Tragedi (2001), AADC (2002), Rumah Ketujuh (2003), Mengejar Matahari (2004), Tentang Dia (2005), 9 Naga (2005), Mendadak Dangdut (2006), Ujang Pantry (2006), Pocong (2006), Mengejar Mas-mas (2007), Cintapuccino (2007), 40 Hari Bangkitnya Pocong (2008), Liat (2008), Sebelah Mata (2008), Kambing Jantan (2009), The Movie (2009), Hantu Rumah Ampera (2009), 5 Elang (2011), and Garuda di Dadaku (2011).

In Batas, Dayak culture is displayed as the background of the location and characterization of the player. One of the characters, Jaleswari is desperate after her husband's death. One day she volunteered to improve the performance of Corporate Social Responsibility program in the field of education which was stopped without clarity. She left for Pontianak, precisely in the Entikong hamlet. She promised to find out the cause of the obscurity and resolve it within two weeks.

Arriving there, she found problematical condition. Teachers who are contracted never last long. There is only one teacher remains, named Adeus, a native of the region who continues to teach. But it turns out that Adeus has a new decision to stop teaching on the results of Otik's coercion, a human trafficker, who wants residents in Entikong to remain stupid. It was this people's ignorance which Otik later used so that his citizens continued to dream of a better life and were tempted to depart for neighboring countries to become laborers. In addition, Adeus also became apathetic because the education system desired by the company was not in line with the expectations of the community, where the lifestyle of the community cannot be separated from traditional regulations. Knowing this, Jaleswari began to arouse the spirit of Adeus.

Not only Adeus, Jaleswari also received threats from Otik. But the spirit of learning aroused the spirit of Jaleswari to fight Otik. This spirit is transmitted to Panglima Galiong Bengker who is the chief of the tribe. Panglima Galiong hopes that Adeus will return to his enthusiasm to teach with the support of Jaleswari.

The presence of Jaleswari as a foreigner from Jakarta and other figures who play a role, shows different representations regarding the meaning of boundaries. This is considering that the concept of boundaries also has many meanings for each individual. As a message delivery medium, this film is interesting to study and explain how boundary meanings are represented by each character.

Based on the background above, the formulated research question is: "How is the boundary meaning presented by the Batas maker through the character in the movie?". So, the purpose of this study is to explain the representation of the boundary meanings presented by filmmakers through each character.

Based on literature search, researchers found three research results that have similarities with this study. First, Representation of Patriarchy in Batas Film (Adipoetra, 2016). This study uses Peirce's semiotic trichotomic method. The researcher reviews his findings using the theory of male-controlled life in patriarchy based on theory from Bhasin. He concluded that Batas as is a film about hope. But the hope is only imagination because it is controlled by men. Women did not get the same opportunity and eventually returned to the domestic sphere.

According to Adipoetra analysis, in the aspect of productive power and female labor, 
this film shows that women cannot escape the area that has been constructed by society, namely domestic. Rules that seem to free actually limit women to make action. Men are always presented as saviors, both from the economy and resources. So that women can never escape the inherent ties of the patriarchal system.

The second study is Semiotic Analysis in Batas Films (Ghamaputri, 2015). This study aims to determine the signs, signifiers, and social reality in Batas movie, so that moral messages can be found in them. The research method used is semiotic analysis from Saussure. In addition, researchers also used observation techniques, library studies, and in-depth interviews. The research findings explained that there were 13 scenes containing moral messages including humanism, culture, struggle, and education awareness.

The third is the research from Setiaputri entitled Representation of Education at the Border in Boundary Film (2015). The researcher reviews the representation of education in Boundary films using the Peirce semiotic analysis method. Through the sign that was present, Setiaputri found that the concept of education represented was different from national education in general. Due to the lack of awareness of education by border communities, the channels of education are socialized through the patterns of life of the people. This then explains that education functions as an agent of social change.

Based on the description of the results of the three previous studies above, the researchers concluded that it was ascertained that there were no studies that had the same title, purpose and method for this study. With this gap, this research is expected to become a scientific reference that contribute to the development of communication science, especially in the fields of culture and creative media related to film. This research is also expected to make a real contribution to the film practitioners and the film industry to improve the quality of their production. For the community, this research is one of the references as well as a reference for understanding the signs and meanings behind audio and visuals of a film.

For Hall, a representation is a production process of the meaning of language (Hall, 2013). Theexplanation of the Hall revealed that representation is the process of producing a meaning and then being developed to other audiences. In some aspects, representation is one of the important processes in analyzing and interpreting a meaning which includes signs, language, and images in representing the meaning contained.

\section{LITERATURE REVIEW}

Representation is not necessarily a transfer of similarity to actual reality, but representation is an expression that has aesthetic values, reconstruction, and a real situation. Through representation, a meaning will be produced and constructed. This happens through a signification process that makes something meaningful. Representation always uses language to convey meaning to self and others. The purpose of language can be realized through words, images, episodes, stories, emotions, facts, and others (Putri, 2014). The shape of the representation depends on the existing sign and image.

The concept of representation in mass media can be seen from several aspects that depend on the nature of the study, including one of them is film. The definition of film according to article 1 paragraph 1 of Indonesian Law No. 33 of 2009 states that film is a cultural art work which is a social institution and mass communication media made based on cinematographic rules with or without sound and can be performed. Basically, films always influence and shape society from the messages contained therein.

The characteristics of the film as a mass media are also able to form a kind of visual public consensus because in films always mix with the values that live in society and public tastes. It can be said, the film summarizes the value of plurality that exists within society (Jaya, 2014). 
A film always has an influence and constructs society based on the contents of the message in it. All records of people's lives are projected onto the screen. The entire community is able to enjoy this audio-visual communication media easily. This is the strength of the film so that it can influence the community directly and indirectly.

A director applies his or her imagination and presents it to the film by taking the exposition component. A variety of films are produced, carried out in the distribution process, and consumed by the public by including ideological messages even though they are not an actual reality. This is what ultimately affects the mindset of the community consciously or unconsciously through certain codes, agreements, and ideologies.

The development of films in Indonesia is quite significant considering the annual number of production. The film industry in Indonesia began to improve in terms of quantity, quality, and the message. Garin Nugroho, Riri Riza, Hanung Bramantyo, Rudy Soedjarwo, and other brilliant director enriched the film industry in the revival of the millennium era. The concept of culture in film is seen as something valuable when it becomes content.

Batas is the first film produced by Marcella Zalianty who also casts the character of Jaleswari in the film. Slamet Raharjo, one of the artists who wrote the script of Batas, described the problems, culture, conflict, and diversity that occur in the film. Batas is a dedication for the community to better understand the meaning of 'boundaries' in life (Kartikasari, 2011).

Batas has been included in several nominations at the Indonesian ASEAN International Film Festival in 2013 including Best Screenplay, Best Film Photography, Best Supporting Actor, and Best Actress. The film is also highly appreciated by the government by conducting screening programs in remote areas in Indonesia such as Papua, East Nusa Tenggara, and several other areas. The target is that people living in the border and remote areas have an idea about how to access transportation and education despite the obstacle they face and continue to strive to pursue their dreams.

\section{METHODS}

This study refers to a critical approach where the politics of media meanings become an important point in it. This paradigm assumes that all the facts that appear in reality are false reality and have been formed and influenced by political, economic, social, cultural, economic and so on. All of these things have been preserved by generations from time to time. The researcher applied Barthes' analysis method in analyzing the denotation elements and connotation elements. Barthes sees another sign that develops in society, namely myth, which is formed from stories that develop in society. According to Barthes, the communication system in myth is a message in which the message is not an object, idea, and concept but rather a means of significance, a form. The myth is conveyed is not only in verbal form but also a mixture of verbal and nonverbal. Generally, myths are closely related to habits, and rituals can form stories. Myths certainly have a historical foundation, both classic and non-classical myths, because myth is the type of reasoning selected through its history. So that the myth may not be reflected immediately.

Semiotics is often used to analyze films. Film researchers will observe more signs in each scene than the storyline. Film and semiotics are related to each other.

Films have parts that are tailored to the message. The part of the sign contained in the film, namely character, background, gesture, costume, property, facial expressions, and dialogue. The object in this study is the Batas movie by Rudi Soedjarwo. This study analyzed its characters, including Ardina Rasti as Ubuh, Arifin Putra as Arif, Marcella Zalianty as Jaleswari, Marcel Domitts as Adeus, and Piet Pagau as Panglima (tribe leader).

The researchers conducted five stages of research. First step is collecting data on all 
the films by Rudi Soedjarwo and choosing particular film based on the suitable themes and genres. After the researcher determines the film in accordance with the theme, then the second stage is observations on the film that has been chosen to understand the intent of the theme, narration, visual, and dialogue. The third stage is the selecting films and other data that will be a reference in analyzing the film and then the researcher makes the original transcripts and make screenshots of the film. The fourth stage is to observe the results obtained in the second stage. At this stage, the researcher begins to conduct semiotic analysis in Batas films by using Roland Barthes's semiotic analysis by looking at the process of meaning that occurs in the film and linking it with elements of denotation, connotation, and myth. The fifth stage is the last stage in the process of this research, which is drawing conclusions from the results of the analysis in the previous stages

\section{RESULTS AND DISCUSSION}

In the analysis, the authors summarize the sign findings into the denotation and connotation levels. Here's the description.

Table 1 Findings sign in Film Limit

\begin{tabular}{|c|c|c|}
\hline \multicolumn{3}{|c|}{ Figures Ubuh } \\
\hline Signs & Denotation & Connotation \\
\hline Background & Forest & state borders \\
\hline Running & rapid movement & $\begin{array}{l}\text { attempt to escape } \\
\text { and saving life }\end{array}$ \\
\hline Apparel & $\begin{array}{l}\text { dirty and bloody } \\
\text { clothes }\end{array}$ & $\begin{array}{l}\text { acts of violence } \\
\text { and harassment }\end{array}$ \\
\hline Wounds & $\begin{array}{l}\text { Open wounds on } \\
\text { the backs of }\end{array}$ & Physical \\
\hline Crying & $\begin{array}{l}\text { turmoil of } \\
\text { emotions }\end{array}$ & Fear \\
\hline rooms & Being silent & Alienation \\
\hline \multicolumn{3}{|c|}{ figures Arif } \\
\hline Signs & Denotation & connotation \\
\hline $\begin{array}{c}\text { group of } \\
\text { people }\end{array}$ & $\begin{array}{c}\text { men drove some } \\
\text { women }\end{array}$ & Trafficking \\
\hline $\begin{array}{l}\text { pistol, } \\
\text { handcuffs, } \\
\text { radio } \\
\text { transmitter }\end{array}$ & $\begin{array}{l}\text { equipment used } \\
\text { by the police in } \\
\text { keeping the security }\end{array}$ & $\begin{array}{l}\text { S elf-d e f e n s e } \\
\text { equipment and } \\
\text { communication } \\
\text { tools }\end{array}$ \\
\hline
\end{tabular}

\begin{tabular}{|c|c|c|}
\hline \multicolumn{3}{|c|}{ figures Jaleswari } \\
\hline Signs & Denotation & connotation \\
\hline Dialogue & $\begin{array}{l}\text { "But It's time to } \\
\text { fight, now we are } \\
\text { together, I'm sure we } \\
\text { can ... " Meaningful } \\
\text { encouragement. }\end{array}$ & $\begin{array}{c}\text { Motivation } \\
\text { and attitude to } \\
\text { struggle }\end{array}$ \\
\hline $\begin{array}{l}\text { Picking up } \\
\text { cell phones }\end{array}$ & $\begin{array}{l}\text { It is difficult to get a } \\
\text { signal }\end{array}$ & $\begin{array}{c}\text { Limitations of } \\
\text { information } \\
\text { services } \\
\end{array}$ \\
\hline Dialogue & $\begin{array}{l}\text { "Their streets may } \\
\text { be better than our } \\
\text { home, but our place } \\
\text { is more beautiful } \\
\text { and richer." mean- } \\
\text { ing that differences } \\
\text { do not cause short- } \\
\text { comings. }\end{array}$ & Optimism \\
\hline \multicolumn{3}{|c|}{ Borneo Leaders } \\
\hline Sign of & Denotation & Connotation \\
\hline $\begin{array}{l}\text { Holding } \\
\text { a Mobile } \\
\text { Phone }\end{array}$ & Confusion & $\begin{array}{l}\text { Technology } \\
\text { illiterate }\end{array}$ \\
\hline $\begin{array}{c}\text { "Became } \\
\text { president." } \\
\text { The } \\
\end{array}$ & idealism & optimism \\
\hline \multicolumn{3}{|c|}{ Figures Adeus } \\
\hline Signs & Denotation & connotation \\
\hline Educational & Sites Learning & $\begin{array}{c}\text { Problems } \\
\text { education }\end{array}$ \\
\hline Dialogue & $\begin{array}{l}\text { It was the language } \\
\text { of Jakarta people, } \\
\text { the language of } \\
\text { people who do not } \\
\text { know this place, } \\
\text { here peopleare con- } \\
\text { crete and realistic. } \\
\text { The circumstances } \\
\text { teach us to be like } \\
\text { this. "Meaning life } \\
\text { on the border. }\end{array}$ & $\begin{array}{l}\text { Conditions and } \\
\text { limitations. }\end{array}$ \\
\hline \multicolumn{3}{|c|}{ Commander figure } \\
\hline Signs & Denotation & connotation \\
\hline Forests & Hunting & Resources Life \\
\hline Dialogue & $\begin{array}{l}\text { "Son, you would } \\
\text { never find some- } \\
\text { thing like this in } \\
\text { Jakarta." That tradi- } \\
\text { tion of hunting only } \\
\text { occurs in the deep } \\
\text { forest. }\end{array}$ & $\begin{array}{c}\text { Cultural } \\
\text { differences }\end{array}$ \\
\hline
\end{tabular}

Source: Findings, 2018 
From the analysis of the six characters in signs, denotations, and connotations, boundary meanings appear in Batas movie. These meanings are constructed from several portrayals of the characters. From here, researchers categorized the understanding of the boundary meanings of each character in the Batas movie.

First, is trauma from violence and sexual abuse. Ubuh feels threatened by bad people chasing her in the middle of the forest. Thus, Ubuh tried to avoid the people by running. The director tries to adapt the place that become the setting in the film. The setting is the border between Indonesia and Malaysia in the Entikong area, West Kalimantan in one of the villages on the border called Gun Tembawang village as the setting. The location of the border that is still untouched by development shows a portrayal of the forest that stretches across the border.

Table 2 Findings Meaning of Limit

\begin{tabular}{ll}
\hline Character & \multicolumn{1}{c}{ Meaning in Batas } \\
\hline & Batas illustrates the intimidation \\
& against women in the form of physical \\
Ubuh & $\begin{array}{l}\text { and sexual abuse. This is a common } \\
\text { problem for women in the border who } \\
\text { are still lacking of the knowledge to } \\
\text { protect themselves. }\end{array}$ \\
& Source: Findings, 2018
\end{tabular}

The visual appearance depicted in the scene gives signs that can construct meaning in the film. Here is the screenshot of a woman in the middle of a jungle with a fearful facial expression revealing a sign from the language we know as trauma. Trauma occurs because of the form of violence committed by others to a woman with abusive or painful actions both verbally or nonverbally.

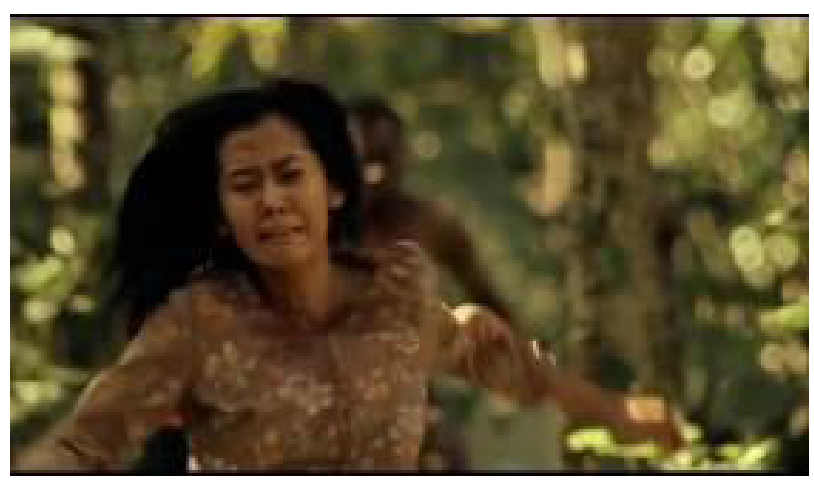

Source: Film Batas, 2011

Figure 1 The Character of the Ubuh being Chased by Two Foreigners in the Border

The evidence of violence towards Ubuh can be seen from the clothes that she wore. Floral patterned clothes is identical with femininity. However, there are blood stains attached to the clothes. The sign indicates that she got physical violence from people who have evil intentions to her.

In the second picture, we can see Ubuh runs and falls into the Indonesian border area and then she is rescued by Arif, a police officer at the border. The figure of Arif who suddenly appeared and then rescued Ubuh, indicated a character of a hero who saved Ubuh that was being chased by people who committed crimes against her. The basic assumption built when seeing Ubuh is falling is to immediately help her. This action is carried out by Arif (the police) as can be seen from the second image where Arif came and approached Ubuh and then held her head from falling to the ground.

Ubuh is not a native of the Indonesian, but Ubuh entered the Indonesian border region because of her fear, which made her not knowing where to run. The border is a place that has saved her life. She managed to escape from the people who had committed acts of violence against her.

Women who are victims of trafficking are sold to become workers in dangerous sectors. Perpetrators usually persuade the victims with job or opportunities to study abroad. In some cases in West Kalimantan, the women victims of trafficking - which in fact are of 
Chinese descent - are made as wives by orders of the men from Hong Kong or Taiwan. This phenomenon is more commonly known as 'photo marriage' in Singkawang City (Sikwan in Niko, 2016).

The construction of thoughts from the figure of Ubuh in the middle of the forest raises the idea that women are vulnerable to crime. According to Sumera (2013), the community considers harassment to be normal, and even considered it as fairness. However, this is the starting point of sexual crime that may occur suddenly. Sexual harassment is the abuse of women's and men's relationships which is detrimental to one party (for being harassed or degrading dignity). So sexual harassment is not only a form of harassment towards women, but it can also occur to men. However, women are mostly sexually abused.

Human rights issues increasingly raised because many women still being differentiated and not getting equal right and many women are considered still not protected. Crimes against humanity that is based on gender is still a part of social life (Prantiasih, 2012).

This causes trauma for women who experience violence and sexual harassment that is detrimental to women. Trauma that occurs affects the pattern of life that due to psychological shock from sexual violence.

Table 3 Meaning Finding

\begin{tabular}{ll}
\hline Character & \multicolumn{1}{c}{ Meaning of border } \\
\hline & Borders have serious problems. \\
& Transnational crime develops in the \\
& area that become the entrance to the \\
& country. Many individuals use forest \\
Arif & trails that are not always guarded by \\
& officers to carry out transnational \\
& crimes such as smuggling illegal \\
& goods, human trafficking, and crimes \\
& between countries. \\
& Source: Findings, 2018
\end{tabular}

Second issue is protection against transnational crime. The figure of Arif as law enforcement officer in this case acts as an intelligence who seeks for information by directly involved in the community.

This shows the attitude of responsibility in Arif's character which focuses on securing border areas from inter-state crime that harms the people at the border. The country's borders still have several problems, especially border access and the entrance of other countries that still have many informal channels so that many people violate the immigration through these informal channels. The role of an intelligence officer is very important to anticipate and provide information relating to actions that violate the law.

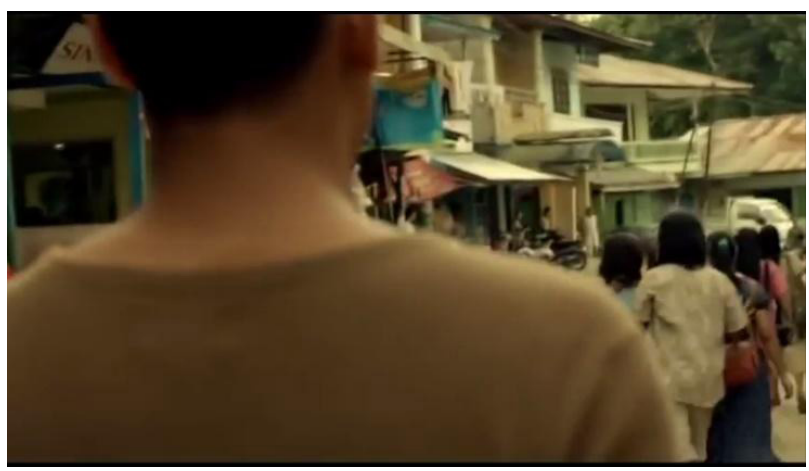

Source: Batas Film, 2011

Figure 2 Arif characters are monitoring the activity of human Trafficking

Crime in border areas varies from illegal smuggling, sales of people, terrorism, drugs, and crime between other countries. This makes a country must strengthen the security of border areas so that transnational crimes that can harm the nation and the country itself can be anticipated.

Marsetio (in Prasojo, 2013) explained some important arguments about local communities at the border, namely (a) The border area is a strategic area that is the face of a country, in this case Indonesia. Because the territories on the border become the entrance for foreign citizens who want to enter the territory of the Republic of Indonesia. In this case Entikong as one of Indonesia's border regions has an important role called "the busiest point of entry and exit". This is what makes the government in 2017 begin to build infrastructure at the country's border post to 
have a positive image as the face of a country.

Furthermore, people on the Indonesian border tend to fall into the category of disadvantaged people. This is what causes many researchers to examine the patterns of life that occur in local communities inland at the border. The Gun Tembawang Dayak tribe community live in the deep forest located in the borders with Malaysia. Dayak people still relies on nature to fulfill their needs. The limited access to infrastructure and services make the people on the border prefer to use Malaysian products that are cheaper and easier to reach. In a study conducted by Prasojo (2013), the findings states that almost $80 \%$ of the people on the border fulfill their daily needs from Malaysian food products.

The third argument is that transnational crimes that enter through border areas result in many cases of crimes. The country's borders is still lacking the infrastructure to make border fortresses, making many border lines open and cannot be monitored continuously by border guards. The condition of the border, which is largely a forest area, is used by individuals to sneak in illegally. The border is the door to the main access to transnational crime in smuggling illicit goods or other crimes.

The third issue is fighting for social care. Jaleswari tries to provide a solution to Adeus to address the problems of education at the border. However, Adeus instead rejected the solution given by Jaleswari and told Jaleswari to go home and stop to provide education at the border because people on the border only needed food and money for their daily needs. Jaleswari did not stop and the she tried to give understanding to Adeus to work together to solve education problems at the border by saying,

"Don't think that I don't have fear, if we are alone we might be afraid. But this is the time for us to fight back, now we are together I am sure we can."

The Jaleswari struggle here reflects a warrior who seeks to solve education problems at the border and provide proper education for border communities. Weak women who have high determination to solve problems at the border compared to men who do not want to act, give rise to the view that women are not always weak but women can rise up and struggle to solve problems.

Table 4: Findings of the Meanings in Batas

\begin{tabular}{ll}
\hline Character & \multicolumn{1}{c}{ Meanings } \\
\hline & $\begin{array}{l}\text { Boundaries is a form of limited services } \\
\text { provided for the development and } \\
\text { progress of society, especially education }\end{array}$ \\
Jaleswari & for children. Here the struggle in \\
providing education at the border is a \\
form of concern for the community at \\
the border.
\end{tabular}

Source: Findings, 2018

Jaleswari who is a migrant figure from Jakarta living in urban areas different from the border area. This raises the question why urban women are shown as fighters in resolving border problems. Urban communities are considered to have high intellectuals and can solve the problems. This is because urban communities get proper education. Education becomes important because it can affect the mindset of the community itself. Education should play a role in resolving conflicts, offering an intelligent solution in solving problems that occur in the community (Sudrajat, 2013).

According to Yasir (in Rosliana, W, Lutfie, Hidayah, \& Aziza, 2015), several problems that have resulted in low education at the border are the low quality of physical facilities, teachers, teacher welfare, and the lack of equal distribution of educational opportunities.

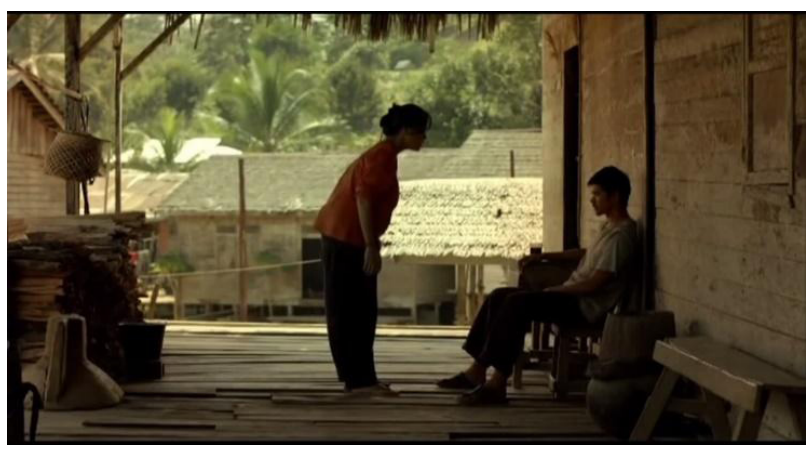

Source: Batas, 2011

Figure 3 Jaleswari is giving motivation to Adeus 
The dialogue stated by Jaleswari "Their streets may be better than here, but our home are more beautiful, we are richer ...", is indicating Jaleswari's passion and concern for helping community at the border. In Batas, Jaleswari is having a serious personal problem. Jaleswari is sad because her husband left her. Whereas the child in her womb must be born without her father. This made Jaleswari shocked and get psychological pressure.

However, she is prepared when she gets the assignments to the border. From this background, it can be seen that Jaleswari whose heart was wounded because of the personal problems she experienced had to stay up because of work assignments that she gets. Nevertheless, Jaleswari did not show her sadness to the people at the border. She still tries to show enthusiasm and give direction to the people to rise even though the conditions on the border were very limited.

Jaleswari who was hurt because her husband left her struggled to continue her life and she was able to stand up by becoming a person who is able to provide motivation to the people in the border who have difficulties in education and life problems. The condition of the border area that is far from community service centers and untouched from the infrastructure has made the Dayak tribe community in the outer area of the border to be a minority and left behind. This is what makes Jaleswari view that border areas are indeed not good in terms of infrastructure, but the border area is very beautiful with natural beauty and the people still strongly hold and show the value of politeness.

It can be concluded from two analytical images of the Jaleswari character that the border is a place that has taught a very meaningful life experience for her. However, the border area has become a new area for herself with a new environment and culture. The struggle to provide decent education and to progress the border area has made Jaleswari not giving up on finding educational solutions in the border areas. Seeing the spirit of border children who are enthusiastic about the school making Jaleswari's sensitivity to social care to help school children become higher. She believes that the hard struggle carried out endlessly will surely produce satisfactory results for the continuity of education at the border.

The fourth finding is desire and reality. The analysis of Adeus's character above shows that Adeus explained the problems of life and education that occurred in the border area to Jaleswari. He explained the circumstances that make Dayak tribal communities on the border prefer trading to meet their daily needs. Here Adeus tried to discuss the reality that happened in the village. How the people there are less interested in sending their children to school but they teach the children more about living in nature by hunting. From this film, Adeus who has a great desire for the progress of the people in the border feels the dilemma of his enthusiasm because he gets threats from individuals who do not want the people on the border to get high education.

\section{Table 5 Findings of Meanings in Batas}

\begin{tabular}{cc}
\hline Character & \multicolumn{1}{c}{ Meanings of } \\
\hline & $\begin{array}{l}\text { Batas are a form of desire and reality } \\
\text { that occurs. Desires that are expected to } \\
\text { make people on the border develop and } \\
\text { Adeus } \\
\text { obtain their rights like the other citizens. } \\
\text { However, the desire must disappear after } \\
\text { seeing the actual conditions and getting } \\
\text { threats from several people. }\end{array}$ \\
\hline & Source: Findings, 2018
\end{tabular}

Problems like this often occur when good intentions are always blocked by malicious intentions that tries to damage. The above view assumes that whenever we want to do the betterment of society, there must be a barrier that disrupts the spirit of fighting for the society. This has changed people's thinking a lot because of individual fears that are natural due to threats given by other people who may harm someone's life. But if we look at the problem above, that there is no easy struggle that certainly has obstacles and trials while living it. Problems should not be avoided, but it must be faced by finding solutions to solve the problems. 


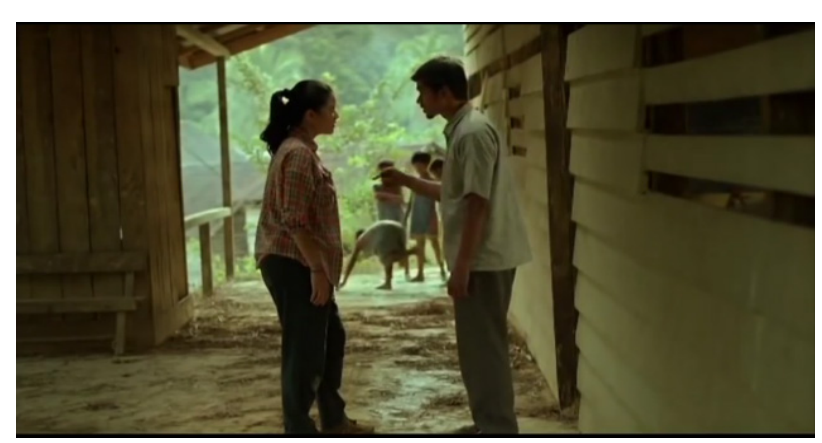

Source: Batas, 2011

Figure 4 Adeus's Character Explaining Problems in the Village to Jaleswari

TheanalysisofAdeus'scharacterindicates the problems of the people on the border i.e. social inequality due to the lack of even distribution provided by the government. The social reality in the village was due to the lack of attention of the government for the people in the border. This has caused insufficient access to transportation, infrastructure and educational services. The reality formed in the scene of the film illustrates the reality of social circumstances in the community living in the border next to Malaysia, which is only about $8 \mathrm{~km}$ away but it has everything that the people needed. Adeus stated that the neighboring country is like heaven since it has everything we wanted such as far better public services.

"The national education system must be able to guarantee equitable education opportunities, improve quality and the relevance and efficiency of education management to face challenges in accordance with the demands of changes in local, national and global life so that education is prepared in a well-planned, directed and sustainable manner" (Law Republic of Indonesia No. 20 of 2003 concerning the National Education System).

The mandate of the law above explains about educational equality for the advancement of society and the state. But the mandate is only a mandate, the condition of education at the Entikong border is very alarming. The reality in the field is not as expected by the community as mandated by the law.
Here Adeus tries to construct the reality that exists from life in the village. Living on the border in the outer part of Indonesia with limited access and services makes the people live in difficulty. All community needs must be obtained with a very heavy struggle. Access for public services provided by the Indonesian government is located very far and it is not sufficient. This makes Adeus feel that there is social inequality in rural communities on the border. Their lives are very different from those in cities, which makes the people living in the border unable to progress and develop. Because there is no means provided by the government in supporting the progress of the people in the border. They only think about how to survive.

The fifth finding from the analysis of the Panglima character shows the figure of the commander who is showing the hunting activities of the Dayak tribe in the middle of the forest on the border. The reality that is portrayed and interpreted aims to show the indigenous life of the Dayak tribe in the border with daily habits such as farming and hunting. This has become a tradition and culture that has been handed down for generations by Dayak tribes in the border.

Table 6 Findings of the Meanings in Batas

\begin{tabular}{ll}
\hline Character & \multicolumn{1}{c}{ Significance of Batas } \\
\hline $\begin{array}{l}\text { Border is evidence of a reflection of } \\
\text { mutual respect for culture and tradition }\end{array}$ \\
Panglim each other, a culture that unites \\
local residents and immigrants who \\
come to the border area.
\end{tabular}

Dayaks tribes live in the deep forest and they are surrounded by rivers. Thus, the Dayak people are very close to nature and depend their lives on nature. Nature provides many benefits for them depending on how they manage the nature. However, the Dayak tribe in Gun Tembawang village is actually very close to the border of Malaysia.

Within the Dayak tribe, there is someone who is respected and exalted as in the film Batas, namely Pangkalima (tribal chief) or who is widely known by the words of the 
Commander of the Bird who acts as head of the regional territory has the authority to decide and give orders to all Dayak tribes in that village. The Commander is a figure who has the power, authority and charisma for the Dayak tribe. The Commander is a Dayak war leader. The Panglima (tribal chief) has a typical weapon of the Dayak tribe namely Mandau with magical powers in it.

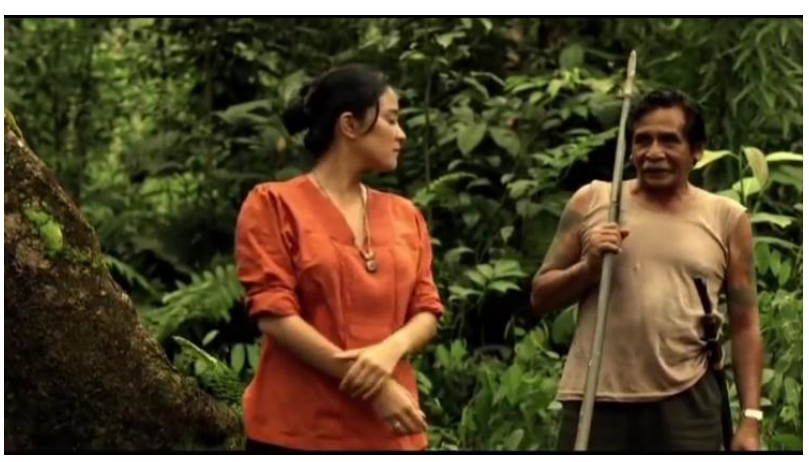

Source: Batas, 2011

Figure 5 Panglima Character Explains Hunting Activities in the Forest

Based on the findings above, for the commander, destiny that has given way that he lives in the forest in the border area does not make him feel disappointed or sad. As the commander or chief of the tribe who is elderly and respected by the Dayak people living in the village, the commander must be able to become an example and role model for the Dayak tribe community in the border. Traditions and customs are one of the rituals carried out by Dayak tribesmen in the border. The habits of Dayak tribes must follow the local customary rules and norms. The Commander as a tribe leader determines and formulates the norms that exist within the community in one area. Customary norms applied in indigenous tribes are listed in Dayak tribal customary law. There are prohibitions and harmful actions regulated in customary law.

The Dayak tribe applies a system that applies in its area, namely customary law is not included in state law. This is what distinguishes the culture and traditions of the Dayak tribe from the general public. The Dayak tribe community still adheres to the laws that apply in the Republic of Indonesia, but the Dayak tribe also has its own rules to control individuals in their area so that there is legal equality in the village community.

From this it can be seen that the commander views life in the border region in the border as not a matter of distress in living, but grateful for the blessings of the creator. Even though they live in the middle of the forest, Dayaks learn how to respect nature as a place to live and a place to fulfill their daily needs.

\section{CONCLUSION}

The five characters represent the boundary meaning of the Batas Film. This meaning is shown through verbal and nonverbal signs displayed by each player. The researcher summarizes the findings and answers for the purpose of this study. The boundary is interpreted as a border region that has complex problems. Access to transnational crime still operates easily, so tight security in the region is very necessary. Despite social and technological disparities, the border region must still feel the slightest education, strive to advance the region, without prioritizing self-interest and leaving the cultural values of their ancestors.

Film is only a representation of reality, not a reflection of reality itself. In the film, the reality has undergone a construction of meaning which causes the presence of differences in various aspects, both verbal and nonverbal. Therefore, the researchers who want to conduct research on film must have in depth and better understanding about film theory and the concept of semiotics to review the true meaning. 


\section{REFERENCES}

Adipoetra, FG (2016). Representasi patriarki dalam Film Batas. Jurnal E-Komunikasi, 4(1), 1-11. Retrieved from https://media. neliti.com/media/publications/77847ID-representasi-patriarki-dalam-filmbatas.pdf

Ghamaputri, N. (2015). Analisis semiotika dalam Film Batas. Universitas Pasundan. Retrieved from http:// repository.unpas.ac.id/11940/

Hall, S. (2013). The work of representation. In Representation: Cultural Representations and Signifying Practices 2 (pp. 1-47).

Jaya, AS (2014). Representasi Seksualitas Perempuan dalam Film Suster Keramas. The Messenger, VI (2), 1-7.

Kartikasari, A. (2011). Batas Produser dan Pemain untuk Marcella Zalianty. Retrieved January 15, 2018, from http://filmindonesia.or.id/article/ batas-produser-dan-pemain-untukmarcella-zalianty\#.Wdc2uoOXfIU

Marwasta, D. (2016). Pendampingan Pengelolaan Wilayah Perbatasan di Indonesia: Lesson Learned dari KKNPPM UGM di Kawasan Perbatasan. Indonesian Journal of Community Engagement, 1(1), 204-216.

Niko, N. (2016). Fenomena Trafficking In Person di Wilayah Perbatasan Kalimantan Barat. Raheema: Jurnal Studi Gender Dan Anak, 4(1), 32-37.

Prantiasih, A. (2012). Hak Asasi Manusia Bagi Perempuan. Jurnal Pendidikan Pancasila Dan Kewarganegaraan, 25(1), 10-15.

Prasojo, ZH (2013). Dinamika Masyarakat Lokal di Perbatasan. Walisongo, 21(2), 417-436.

Putri, AP (2014). Representasi Citra Perempuan dalam Iklan Shampoo Tresemme Keratin Smooth di Majalah Femina. E-Journal Ilmu Komunikasi,

$$
\text { 2(2), 104-115. }
$$

Rosliana, L., W, FH, Lutfie, W., Hidayah, K., \& Aziza, TN (2015). Manajemen perbatasan fokus inovasi pendidikan di perbatasan kalimantan utara. Jurnal Borneo Administrator, 11(3), 316-339.

Setiaputri, DA (2015). Representasi pendidikan di perbatasan dalam Film Batas. Universitas Katolik Widya Mandala Surabaya. Retrieved from http://repository.wima.ac.id/6633/1/ abstrak.pdf

Sudrajat. (2013). Revitalisasi pendidikan multikultural dalam pembelajaran sejarah. Informasi, XXXIX(1), 32-42.

Sumera, M. (2013). Perbuatan Kekerasan/ Pelecehan Seksual Terhadap Perempuan. Lex et Societatis, I(2), 3949.

Widiyanta,D.(2010).Upayamempertahankan pulau terluar. Informasi, XXXVI(2). 